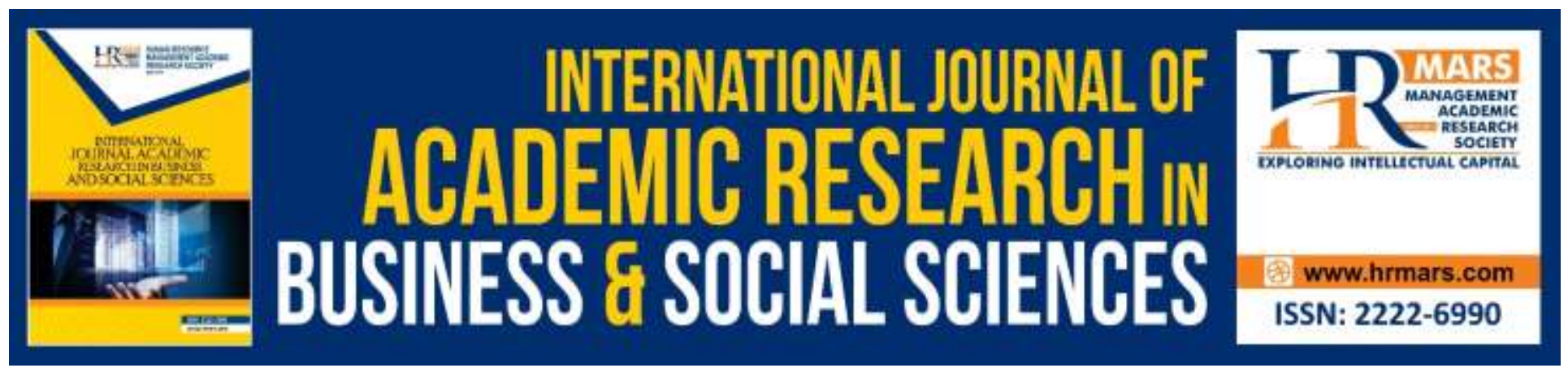

\title{
Emotional Intelligence, Social Supports, Technology Advancement, Work Condition and Work-Life Balance among Employees
}

Muhammad Faizal Samat, Fathin Safiera Mohd Zaki, Effa Radzlia Md Rasidi, Fatin Farhana Roshidi, Zahirah Hamid Ghul

To Link this Article: http://dx.doi.org/10.6007/IJARBSS/v10-i5/7169

DOI:10.6007/IJARBSS/v10-i5/7169

Received: 04 March 2020, Revised: 09 April 2020, Accepted: 25 April 2020

Published Online: 01 May 2020

In-Text Citation: (Samat et al., 2020)

To Cite this Article: Samat, M. F., Zaki, F. S. M., Rasidi, E. R. M., Roshidi, F. F., \& Ghul, Z. H. (2020). Emotional Intelligence, Social Supports, Technology Advancement, Work Condition and Work-Life Balance among Employees. International Journal of Academic Research in Business and Social Sciences, 10(5), $23-32$.

Copyright: @ 2020 The Author(s)

Published by Human Resource Management Academic Research Society (www.hrmars.com)

This article is published under the Creative Commons Attribution (CC BY 4.0) license. Anyone may reproduce, distribute, translate and create derivative works of this article (for both commercial and non-commercial purposes), subject to full attribution to the original publication and authors. The full terms of this license may be seen

at: http://creativecommons.org/licences/by/4.0/legalcode

Vol. 10 , No. 5, 2020, Pg. $23-32$

http://hrmars.com/index.php/pages/detail/IJARBSS

JOURNAL HOMEPAGE

Full Terms \& Conditions of access and use can be found at http://hrmars.com/index.php/pages/detail/publication-ethics 


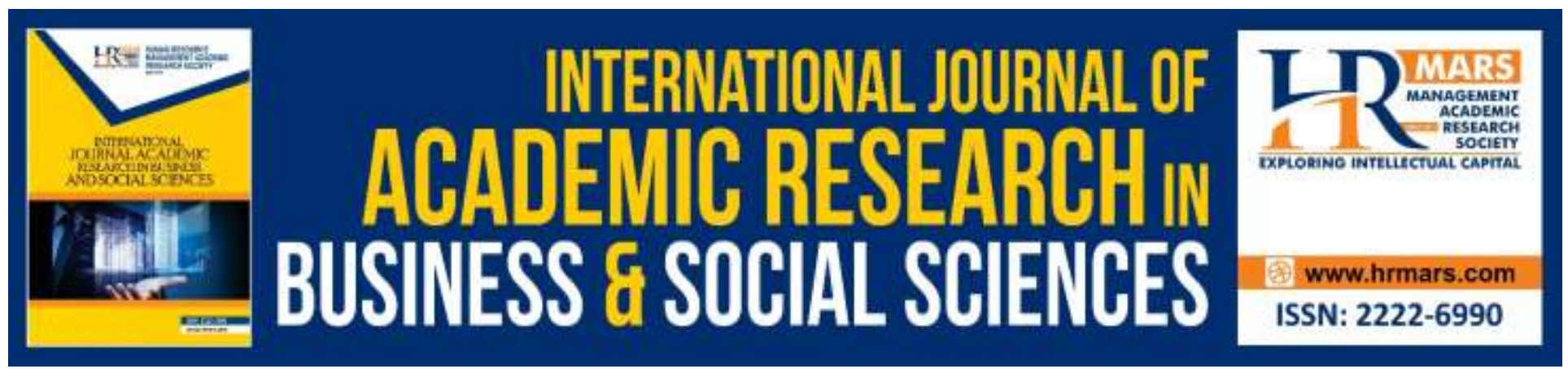

\title{
Emotional Intelligence, Social Supports, Technology Advancement, Work Condition and Work-Life Balance among Employees
}

\author{
Muhammad Faizal Samat ${ }^{1}$, Fathin Safiera Mohd Zaki², Effa Radzlia \\ Md Rasidi ${ }^{3}$, Fatin Farhana Roshidi ${ }^{4}$, Zahirah Hamid Ghul ${ }^{5}$ \\ ${ }^{1}$ Universiti Teknologi MARA, 40450 Shah Alam, Selangor, 2,3,4 Universiti Teknologi MARA Cawangan \\ Kelantan, Bukit IImu, 18500 Machang, Kelantan, 5 Universiti Teknologi MARA Cawangan Johor, Jalan \\ Universiti Off, KM 12, Jalan Muar, 85000 Segamat, Johor
}

Email: faizal951@uitm.edu.my

\begin{abstract}
In order to survive with the economic crisis nowadays, people tend to do more than one job to earn income. It is more difficult for a person with a big family with low income to balance their work and life. This situation leads to the unhealthy lifestyle with no work life balance. Thus, this paper aims to investigate the relationship between emotional intelligence, social supports, work condition and technology advancement with work life balance. For the purpose of this study, sets of questionnaires were distributed among working adults by using non-probability sampling technique. 139 respondents were recorder and the hypotheses were tested by using Smart-PLS version 3. Based on the result, social supports and work condition were found to be significant with work life balance. However, emotional intelligence and technology advancement were found to be not significant with work life balance. It is suggested for future research to collect more respondents around the country in order to get more reliable results.
\end{abstract}

Keywords: Emotional Intelligence, Social Supports, Technology Advancement, Working Condition, Work-Life Balance.

\section{Introduction}

Work-life balance is an important aspect of a healthy work environment. However, the terms of "work-life balance" has extinct in employees for last few years. Carnicer, Sanchez, and Perez (2003) found that the number of individuals with significant responsibilities both at work and with family: single parents, working women, dual-career couples, and fathers heavily involved in the past two decades. These changes have reasons on why the work-life balance is no more important for a few employees. 
Due to the effect of the recession on the relationship between work and life, the European Social Survey found that to some degree shortened working hours had alleviated tensions between work and life. OECD (2016) data suggest that the quality of jobs has steadily declined in many European countries during the severe and prolonged economic crisis, negatively affecting job security and the quality of the work environment. The work pressure has increase dramatically in recent decades for those employees work for long hour of working period.

Work life balance which primarily deals with an employee's ability to properly prioritize between work and his or her lifestyle, social life, health, family etc, is generally linked with employee productivity (Shadab \& Arif, 2015). According to The Star Online (2019), Kuala Lumpur has the worst overall work-life balance among 40 major cities in the world. Kuala Lumpur, Malaysia holds the 4th place of top overworked cities in the world. The Sun Daily article stated that Kuala Lumpur is one of the most expensive cities in Asia which on rank 141st in the world. Employees need to do more than one job, or they will work overtime to support themselves due to high costs of living that lead to unbalance work life. Contrary, some employees are not willingly to do the job but they were asked by their bosses to do so. Employers have no right to give work orders when you have officially clocked off (Abdul Halim, 2017). According to The Malaysian Reserve (2019) indicates that to a recent survey by Monster.com, 39 per cent of Malaysian employees say uncooperative bosses are a barrier to achieving work-life balance, while 37 per cent say their workplace does not provide them with the necessary tools required to work from home. Employees across Malaysia do not have a great experience with their attempts to balance time in the office with time at home, as nearly half of them said they can "only sometimes" manage. When the employees cannot manage their time effectively, this will contribute to a few problems to him or herself such as lack of time for their families. Therefore, the objectives of this study are:

- There is a relationship between emotional intelligence towards work life balance

- There is a relationship between social supports towards work life balance

- There is a relationship between technology advancement towards work life balance

- There is a relationship between working condition towards work life balance

\section{Literature Review}

Studies have demonstrated that work-life balance is not about dividing time between work life and non-work life. It must be done by reducing the conflict between two realms by managing the various roles and responsibilities (Kumarasamy, Pangil, \& Isa, 2015). According to a survey by Ernst \& Young, one in three full-time employees in some of the world's largest economies said it become more difficult to maintain a healthy work-life balance in the last five years. Technologies nowadays burden the employees as they will receive work anytime through mobile phones. Based on the analysis of Duxbury and Smart (2011) on the survey found that 70 per cent of professional employees agreed that mobile technology had increase their workloads. This is one of the reasons the employee could not balance their work and personal life. The work often affects family and social life, while family pressures at other times affect the performance of the work (Fu \& Shaffer, 2001; Nabong, 2012; Reddy, Vranda, Ahmed, Nirmala \& Siddaramu, 2010). Futhermore, it has been shown that high levels of total (paid) working hours lead to tensions between work and life. McGinnity and Russell (2013) found that economic crisis contributes to unbalance work and family life as it is due to financial insecurity. 
INTERNATIONAL JOURNAL OF ACADEMIC RESEARCH IN BUSINESS AND SOCIAL SCIENCES

Vol. 10, No. 5, May, 2020, E-ISSN: 2222-6990 @ 2020 HRMARS

\section{Emotional Intelligence}

Kalyani, Priyadarshini, Ravinder and Asha (2017) defined emotional intelligence as the capability of individuals to recognize their own emotions and those of others. The same study stated that employees with higher emotional intelligence have better work life balance and emotional intelligence is an effective way to incorporate, improve and offer better work and family life. The study used 170 employees as their sample size who work in IT sector of the age group 25-50 years old, of different income groups of junior and middle level management. From their finding, Emotional Intelligence and Work Life Balance are moderately and positively correlated. Another study done by Mokana, Faizuniah and Faizal (2015) to show the influence of emotional to work life balance. According to them, with emotional intelligence, we will be able to understand our own need and relate to those whom we work with better, and as a consequence we will able to complete our work more effectively and thus maintain our work-life balance. Their finding is the emotional intelligence was found positively related to work life balance. Therefore, this study proposed that:

$\mathrm{H} 1$ : There is a relationship between emotional intelligence and work life balance.

\section{Social Supports}

Social support is defined as "the social resources that persons perceive to be available or that are actually provided to them by non-professionals in the context of both formal support groups and informal helping relationships (Gottlieb and Bergen, 2010). We need to have a strong social support network during the phase of reaching our goals or handle a conflict. Study done by Achour, Shahidra, Bahiyah, Roslan and Yakub (2017) to examine the relationship of work-family demand with employee's well-being, and the role of management/supervisory support. Management/supervisory support would moderate the relationship of work-family demands with employees' well-being were the hypothesis that were proposed by the researchers. Total of 250 working female academicians working in research universities in Kuala Lumpur, Malaysia were used as respondents where their ages ranged from 30 to 60 years old. The result of the study has proved that management and supervisory support strengthens the relationship between work-family demands and employees' well-being. The authors state that management and supervisory support plays an important role in balancing work demands and family roles and also in increasing working female academicians' wellbeing. The study shows that management/supervisor support reduced work-family conflict and workfamily demands. Hence, work family demands and developing and improving well-being of employees is moderated by the management/supervisory support.

Research by Achour, Shahidra, Bahiyah, Roslan and Yakub (2017) found out that management and supervisory support strengthens the relationship between work-life demands and employees' wellbeing. Moreover, supervisory and management support have a significant and positive relationship with employee well-being. Study on organizational support done by Mokana, Faizuniah and Faizal (2015) show that organizational support was found positively and significantly related to work life balance. Therefore, it can be hypothesized as:

$\mathrm{H} 2$ : There is a relationship between social supports and work life balance.

Technology Advancement

Technology advancement in the means of working through technological gadgets like smartphones, tablets \& other devices that enable employees to stay connected with work all the time (Easmin, 
INTERNATIONAL JOURNAL OF ACADEMIC RESEARCH IN BUSINESS AND SOCIAL SCIENCES Vol. 10, No. 5, May, 2020, E-ISSN: 2222-6990 @ 2020 HRMARS

Anwar, Dovash and Karim, 2019). Technology development has given a greater sense of mobility in individuals' daily lives (Holden and Sunindijo, 2018). This increased mobility and interconnectedness has enabled the workforce to work from home, become more itinerant, thus allowing individuals to communicate while in transit, and be available 24 hours a day, seven days a week (Wajeman et al., 2010).

According to Githinji and Wekesa (2017), a greater sense of work life balance and increased productivity in the workplace can be fostered with virtual work programs. This program would make the employees to work in flexible location and time without need to travel and eliminate the office space. This can be supported by Holden and Sunindijo (2018), work-life balance is supposed to be good in using information and communication technologies (ICTs) because it increased the employee's flexibility, allows them to complete work in a non-work environment, thus, facilitating social and family needs. However, according to Easmin, Anwar, Dovash and Karim (2019), because of technological advancement, there is employee needs to bring their incomplete task out of the office which create negative impact on personal life. These actions make the employees tend to stay connected with the technology to contact with manager regarding to respond about work even after working hours and at the weekends. These claims can be supported by Hubbard (2016), the continuous emergence of new technologies will bring the pressures for individuals where they need to complete work tasks, or immediately respond to work inquiries, are constantly increasing. More work pressures caused from advancement in technology has affected the employees' stress level to a much larger extent (Fazili and Khan, 2017). Hence, the current study proposed the following:

$\mathrm{H} 3$ : There is a relationship between technology advancement and work life balance.

\section{Work Condition}

According to Babić and Bakotić (2013), Work condition is the conditions under which job is performed can be different - from those completely comfortable to those very difficult and dangerous to employees' life and health. The researchers said that the factors of working condition related to the organization such as duration of the work shift, work schedule, working time, work and excessive strain. Working condition is one of significant factor for employee to have a good quality of life that would affect their physical and mental health. Besides, working conditions will promote a harmony amongst work and life enhances employee achievement and inspiration (Tanaka et al., 2011). The findings of this study are also supported by the research conducted done by Asad et al., (2018), there is a positive relationship between working conditions and work life balance. It means that if there is any change in working conditions then work life balance will also affected.

Flexible working hours are becoming important to the workplaces in offering flexible working hours to employees due to the benefits that flexibility gives to both employee and employer (Shagvaliyeva and Yazdanifard, 2014). According to Russel, Helen and Mcginnity (2015), the researchers said that working hours are very strongly associated with satisfaction with work-life balance: those who work longer hours are much less satisfied with the balance between work and family life. This is because employee working condition have influence their work life balance where they need to work over their own working time and have less time to spend with the children, spouses and family. Furthermore, in an observation- based study by Lederer et,al. (2018), the findings have shown that working condition under increased pressure from consolidated working hours, employees increased 
INTERNATIONAL JOURNAL OF ACADEMIC RESEARCH IN BUSINESS AND SOCIAL SCIENCES Vol. 10, No. 5, May, 2020, E-ISSN: 2222-6990 @ 2020 HRMARS

pressure to perform during work hours contributes to emotional exhaustion and poor work-life balance. Working hours tends to keep them busy in their professional work. Where daily course of work is concerned with the time allocation for each duty and responsibility handled by individual (Narkhede \& Lal,2018). So, this study proposed that:

$\mathrm{H} 3$ : There is a relationship between work condition and work life balance.

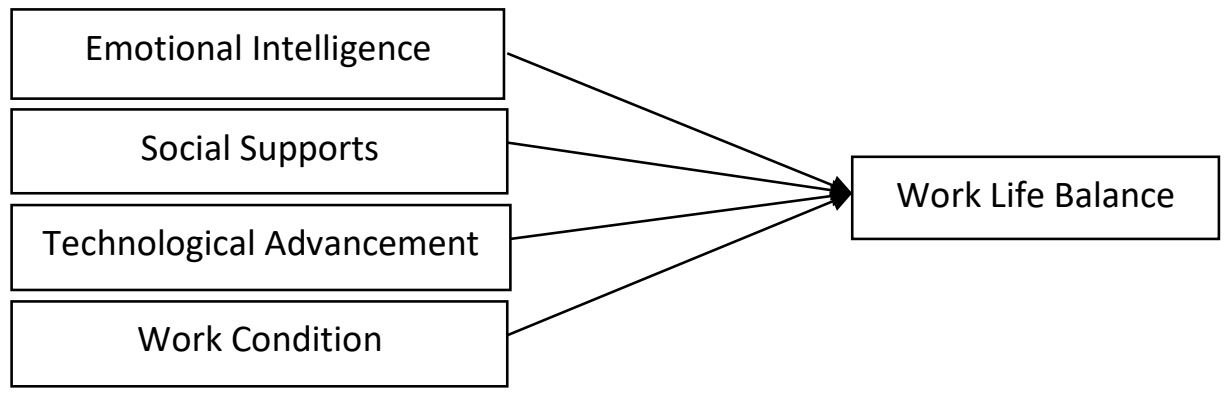

Figure 1: Theoretical Framework

\section{Methodology}

This study used descriptive research design in order to seek the relationship between factors affecting work-life balance among employees in Malaysia. The data was collected by using quantitative approach, specifically questionnaires. As to reach the targeted population, judgmental sampling was used with criteria that the respondents must come from working adults. After the major data collection, 158 questionnaires were returned. However, only 139 completed questionnaires were further analyzed by using Smart-PLS version 3. The findings of the data were presented in the next section.

\section{Result and Discussion}

Respondents' Demographic Profiles

Frequency analysis was run in order to analyze the demographic profile of the respondents. From the result, it shows that 31.7 percent or 44 respondents were male, while 68.3 percent or 95 respondents were female. In term of age, 61.9 percent or 86 respondents is between 18 to 30 years old, 34.5 percent or 48 respondents is between 30 to 50 years old, while only 3.4 percent or 5 respondents is above 50 years old. In term of age, out of 139 respondents, 53.2 percent or 74 respondents were single, while 46.8 percent or 65 respondents were married. Lastly, 70.5 percent or 98 respondents were permanent staff, 18.0 percent or 25 respondents were temporary staff, while only 11.5 percent or 16 respondents were contract staff.

Normality

Table 1.1 Normality Result

\begin{tabular}{llllll}
\hline & $\begin{array}{l}\text { Work Life } \\
\text { Balance }\end{array}$ & $\begin{array}{l}\text { Emotional } \\
\text { Intelligence }\end{array}$ & $\begin{array}{l}\text { Social } \\
\text { Supports }\end{array}$ & $\begin{array}{l}\text { Work } \\
\text { Condition }\end{array}$ & $\begin{array}{l}\text { Technology } \\
\text { Advancement }\end{array}$ \\
\hline Skewness & -.678 & -.021 & -.706 & .308 & -.172 \\
\hline Kurtosis & -.067 & -.596 & -.128 & -.124 & .794 \\
\hline
\end{tabular}

In order to test for normality of the data, skewness and normality was performed. Based on Table 1.1 , skewness and kurtosis value ranges from -3 to 3 . Therefore, all the variables can be said (work 
INTERNATIONAL JOURNAL OF ACADEMIC RESEARCH IN BUSINESS AND SOCIAL SCIENCES Vol. 10, No. 5, May, 2020, E-ISSN: 2222-6990 ㄷ 2020 HRMARS

life balance, emotional intelligence, social supports, work condition and technology advancement) are normally distributed.

Multicollinearity

Multicollinearity occurs when there are correlations among variables. According to Tabachnick and Fidell (1996), this happens if a correlation between two or more variables is 0.9 or greater and in order to overcome this problem, one of the variables is removed from further analysis. Based on the results, all the correlation values of the variables are below 0.9 , thus no multicollinearity problem was detected.

Table 1.3 Correlation Coefficient

\begin{tabular}{|c|c|c|c|c|c|}
\hline & $\begin{array}{c}\text { Work Life } \\
\text { Balance }\end{array}$ & $\begin{array}{c}\text { Emotional } \\
\text { Intelligence }\end{array}$ & $\begin{array}{c}\text { Social } \\
\text { Supports }\end{array}$ & $\begin{array}{c}\text { Work } \\
\text { Condition } \\
\end{array}$ & $\begin{array}{c}\text { Technology } \\
\text { Advancement }\end{array}$ \\
\hline \multicolumn{6}{|l|}{ Work Life } \\
\hline Balance & 1 & & & & \\
\hline Emotional & & & & & \\
\hline $\begin{array}{l}\text { Intelligence } \\
\text { Social }\end{array}$ & .077 & 1 & & & \\
\hline Supports & $.346 * *$ & $.184^{* *}$ & 1 & & \\
\hline Work & & & & 1 & \\
\hline Condition & $.214^{* *}$ & $.398 * *$ & $.247 * *$ & & \\
\hline Technology & & & & . & \\
\hline Advancement & .024 & $.256 * *$ & -.080 & $.245^{* *}$ & 1 \\
\hline
\end{tabular}

Test of Hypotheses

Hypothesis testing were used to test whether the stated hypothesis can be accepted or rejected.

Table 1.4 Test of Hypotheses

\begin{tabular}{|c|c|c|c|c|c|}
\hline & $\begin{array}{c}\text { Work } \\
\text { Life } \\
\text { Balance }\end{array}$ & $\begin{array}{c}\text { Emotional } \\
\text { Intelligenc } \\
\text { e towards } \\
\text { Work Life } \\
\text { Balance }\end{array}$ & $\begin{array}{c}\text { Social } \\
\text { Supports } \\
\text { towards } \\
\text { Work Life } \\
\text { Balance }\end{array}$ & $\begin{array}{c}\text { Technology } \\
\text { Advancemen } \\
t \\
\text { towards } \\
\text { Work Life } \\
\text { Balance }\end{array}$ & $\begin{array}{c}\text { Work } \\
\text { Condition } \\
\text { towards } \\
\text { Work Life } \\
\text { Balance }\end{array}$ \\
\hline Std Beta & & 0.296 & 0.260 & 0.057 & 0.386 \\
\hline Std Error & & 0.152 & 0.276 & 0.000 & 0.271 \\
\hline$t$-value & & 1.014 & 3.676 & 0.505 & 2.920 \\
\hline$p$-value & & 0.155 & 0.000 & 0.307 & 0.002 \\
\hline$U L$ & & -0.388 & 0.158 & -0.191 & 0.111 \\
\hline$L L$ & & 0.455 & 0.389 & 0.171 & 0.419 \\
\hline$f^{2}$ & & 0.112 & 0.087 & 0.004 & 0.104 \\
\hline VIF & 0.835 & 0.123 & 0.277 & 0.241 & 0.335 \\
\hline
\end{tabular}

Based on Table 1.4, work life balance has the positive relationship with social supports (t-value=3.676, $p$-value $=0.000$ ) and work condition ( $t$-value $=2.920, p$-value $=0.002)$. However, emotional intelligence 
INTERNATIONAL JOURNAL OF ACADEMIC RESEARCH IN BUSINESS AND SOCIAL SCIENCES

Vol. 10, No. 5, May, 2020, E-ISSN: 2222-6990 @ 2020 HRMARS

was found to has not significant with work life balance ( $t$-value $=1.014, p$-value $=0.155$ ). Technology Advancement also was found to be not significant with work life balance (t-value $=0.505, p$ value $=0.307)$.

\section{Conclusion}

The study was conducted to investigate the potential relationship between emotional intelligence, social supports, work condition and technology advancement with work life balance. Result shows that there was a positive relationship between social supports and work condition with work life balance. However, emotional intelligence and technology advancement were found to be not significant with work life balance. According to Achour, Shahidra, Bahiyah, Roslan and Yakub (2017), it is recommended that management or supervisor should provide their full support to the employee either moral or physical in order to reduce stress in workplace thus promote work life balance. Moral support that management could give to their employees including counseling, while physical support by providing nursery for their kids. In addition, management should practice only works during working hours in order to promote work life balance (Noraini, 2015). In term of emotional intelligence, respondents found it has not significant with work life balance because respondents may manage their emotion well. While, technology advancement also was found to be not significant with work life balance due to technology is much needed in daily life.

Significantly, this study benefits to the policy maker in designing the workforce act as a guidelines to the employer in order to support work life balance. Employee who will be able to balance between their work and personal life will nurture the positive environment in workplace, thus being more productive.

\section{References}

Achour, M., Abdul Khalil, Binti. S., Ahmad, B., Nor, M., and Yusoff, Z. Bin. M. M. (2017), "Management and supervisory support as a moderator of work-family demands and women's well-being: $A$ case study of Muslim female academicians in Malaysia", Humanomics, Vol. 33 No. 3, pp. 335356. Retrieved on December 7, 2019 from https://doiorg.ezaccess.library.uitm.edu.my/10.1108/H-02-2017-0024

Achour, M., Abdul Khalil, Binti. S., Ahmad, B., Nor, M., and Yusoff, Z. Bin M. M. (2017), "Management and supervisory support as a moderator of work-family demands and women's well-being: A case study of Muslim female academicians in Malaysia", Humanomics, Vol. 33 No. 3, pp. 335356. https://doi-org.ezaccess.library.uitm.edu.my/10.1108/H-02-2017-0024

Carnicer, M. P., Sanchez, A. M., Pérez, M. P., \& Jiménez, M. J. V. (2004). Analysis of internal and external labour mobility. Personnel Review.

Duxbury, L., \& Smart, R. (2011). The "myth of separate worlds": An exploration of how mobile technology has redefined work-life balance. In Creating balance? (pp. 269-284). Springer, Berlin, Heidelberg.

Easmin, R., Anwar, T., Dovash, R. H., \& Karim, R. (2019). Improving Work Life Balance: A Study on Employees in Private Commercial Banks of Bangladesh. Journal of Business and Management. Retrieved December 5, 2019 from http://www.iosrjournals.org/iosr-jbm/papers/Vol21issue5/Series-8/A2105080112.pdf 
INTERNATIONAL JOURNAL OF ACADEMIC RESEARCH IN BUSINESS AND SOCIAL SCIENCES

Vol. 10, No. 5, May, 2020, E-ISSN: 2222-6990 @ 2020 HRMARS

Fazili, A. I., \& Khan, O. F. (2017). A Study on the Impact of ICT on Work Life Balance. Life Science Journal. Retrieved December 5, 2019 from http://www.lifesciencesite.com/lsj/life140517/01_32088lsj140517_1_4.pdf

Fu, C. K., \& Shaffer, M. A. (2001). The tug of work and family. Personnel review.

Githinji, F., \& Wekesa, D. S. (2017). The Influence of Technology on Employees' Work Life Balance in the Insurance Industry. Journal of Humanities and Social Science. Retrieved December 5, 2019 from http://www.iosrjournals.org/iosr-jhss/papers/Vol.\%2022\%20lssue5/Version5/D2205052126.pdf

Gottlieb, B. H., and Bergen, A. E. (2010), "Social support concepts and measures", Journal of Psychosomatic Research, Vol. 69 No. 5, pp. 511-520.

Halim, A. K. (2017). Reality Study of Managerial Ability of Managers of Community Learning Center (CLC). In 3rd NFE Conference on Lifelong Learning (NFE 2016). Atlantis Press.

Holden, S. T., \& Sunindijo, R. Y. (2018). Technology, Long Work Hours, and Stress Worsen Work-life Balance in the Construction Industry. Semantic Scholar. Retrieved December 5, 2019 from https://pdfs.semanticscholar.org/3f24/76a4623d367cfc45418ceece48b9607edd86.pdf?_ga $=2.58753646 .2127652824 .1575790711-1745778163.1573140207$

Hubbard, A. (2016) (n.d). The effect of technology on work-life balance: Women in higher education. JMU Scholarly Commons. Retrieved December 5, 2019 from http://commons.lib.jmu.edu/cgi/viewcontent.cgi?article=1109\&context=master201019

Kalyani Sakalle, Priyadarshini Dixit, Dr Ravinder Kaur, Dr Asha Nagendra (2017) Triggers of Employee Life Cycle: An Empirical Study on Emotional Intelligence influencing Work Life Balance in IT Sector. Retrieved on December 3, 2019, from http://euroasiapub.org/wpcontent/uploads/2017/12/17ESSDecSep-016.pdf

Kumarasamy, M. M., Pangil, F., \& Mohd Isa, M. F. (2016). The effect of emotional intelligence on police officers' work-life balance: The moderating role of organizational support. International Journal of Police Science \& Management, 18(3), 184-194.

Lederer, W., Paal, P., Langen, D. V., Sanwald, A., Traweger, C., \& Kinzl, J. F. (2018). Consolidation of working hours and work-life balance in anaesthesiologists - A cross-sectional national survey. PloS one. Retrieved December 6, 2019 from https://www.semanticscholar.org/search?year\%5B0\%5D=2014\&year\%5B1\%5D=2019\&q=wor king\%20hour\%20and\%20work\%20life\%20balance\&sort=relevance

McGinnity, F., \& Russell, H. (2015). Work-life balance, working conditions and the Great Recession. In The changing worlds and workplaces of capitalism (pp. 201-220). Palgrave Macmillan, London.

Mokana, F. P., and Isa, M. F. M. (2015). Individual, Organizational and Environmental Factors Affecting Work-Life Balance

Nabong, T. K. M. (2012). An exploratory study of work-family conflicts and enrichment of front-line hotel employees in the Philippines (Master's thesis, University of Stavanger, Norway).

Narkhede, S. M., \& Lal, N. (2018). The Effects of Working Hours on Health and Work Life Balance. Retrieved December 6, 2019 from https://www.semanticscholar.org/paper/The-Effects-ofWorking-Hours-on-Health-and-Work-Narkhede-

Lal/61014a34ccf6f102766784fba74ca2baddb7d6b7 
INTERNATIONAL JOURNAL OF ACADEMIC RESEARCH IN BUSINESS AND SOCIAL SCIENCES

Vol. 10, No. 5, May, 2020, E-ISSN: 2222-6990 @ 2020 HRMARS

Noraini, N. (2015). Work-life balance policies in Malaysia: theory and practice. Retrieved December 6, 2019 from https://www.researchgate.net/publication/315829306_Worklife_balance_policies_in_Malaysia_theory_and_practice

OECD, K. (2016). OECD science, technology and innovation outlook 2016.

Reddy, N. K., Vranda, M. N., Ahmed, A., Nirmala, B. P., \& Siddaramu, B. (2010). Work-Life balance among married women employees. Indian Journal of Psychological Medicine, 32(2), 112.

Helen, R., \& Frances, M. (2015). Work-Life Balance, Working Conditions and the Great Recession. 10.1057/9781137427083_11. Retrieved on December 5, 2019 from https://www.researchgate.net/publication/281449405_Work_life_Balance_Working_Conditi ons_and_the_Great_Recession

Shadab, M., \& Arif, K. (2015). Impact of work-life balance on job satisfaction a case of health care services in pakistan. Developing Country Studies, 5(9), 132-138.

Shagvaliyeva, S., \& Yazdanifard, R. (2014). Impact of Flexible Working Hours on Work-Life Balance. Retrieved December 5, 2019 from https://pdfs.semanticscholar.org/8d24/526f335e3b96346279d16a9b57d9aa38faa5.pdf?_ga= 2.122793160.2127652824.1575790711-1745778163.1573140207

Tabachnick, B. G., \& Fidell, L. S. (1996). Using multivariate statistics. Northridge. Cal.: Harper Collins.

Tanaka, S., Maruyama, Y., Ooshima, S., \& Ito, H. (2011). Working condition of nurses in Japan: awareness of work-life balance among nursing personnel at a university hospital. Journal of clinical nursing, 20(1-2), 12-22. Retrieved December 6, 2019 from http://europeanscience.com/eojnss/article/view/5253/pdf

The Sun Daily: KL rises in world's most expensive cities list. (2019). Retrieved on December 1, 2019 from https://www.thesundaily.my/local/kl-rises-in-world-s-most-expensive-cities-listMF1025349

Wajcman, J., Rose, E., Brown, J. E., and Bittman, M. (2010). Enacting virtual connections between work and home. Journal of Sociology, Volume 46, (2010), pp. 257-275.

Yadav, T., \& Rani, S. (2015). Work life balance: challenges and opportunities. International Journal of Applied Research 2015; 1(11); 680-684. Retrieved December 5, 2019 from https://pdfs.semanticscholar.org/8e55/f4020767051f01233eb6ceceffb9432097e5.pdf?_ga=2. $62603887.2127652824 .1575790711-1745778163.1573140207$. 